\title{
SOCIAL MEDIA STRATEGIES TO PROTECT BRAND IMAGE AND CORPORATE REPUTATION IN THE DIGITAL ERA: A DIGITAL INVESTIGATION OF THE ENI VS. REPORT CASE
}

\author{
Riccardo Rialti ${ }^{*}$ Lamberto Zollo* *, Alessandro Caliandro ** , \\ Cristiano Ciappei***
}

\begin{abstract}
Over the last decade digital technologies have significantly affected branding strategies and corporate reputation monitoring. Due to the diffusion of digital platforms, stakeholders and consumers have become more engaged in marketing strategies. Specifically, the "consumer decision journey" has represented a new paradigmatic shift in recent marketing literature. The advent of social networking sites has indeed caused an increase of digital touch points, which foster the connection between brand strategists and consumers. Hence, nowadays consumers may directly express their opinions about companies' practices and products using the Internet. Because of this emerging phenomenon, modern marketing strategies are progressively focusing on preserving corporate reputations in the digital environment. In order to better understand how monitoring corporate reputations and responding to consumers to avoid the rise of negative brand perceptions, this explorative paper analyses the digital response strategy implemented by Eni, the largest Italian oil and gas company. The case explored consists of a digital investigation on Twitter, aimed at investigating how Eni's digital counterattack strategies affected consumers' perceptions after accusations moved by Report, a popular Italian journalism TV programme. The conclusions suggest that real-time digital counterattack strategies on social networking sites represent effective strategies to preserve corporate reputations as perceived by customers.
\end{abstract}

Keywords:Digital Branding, Corporate Reputation, Brand Image, Crisis Management, Social Network, Digital Investigation.

* Università degli Studi di Firenze. E-mail: riccardo.rialti@unifi.it.

** Università degli Studi di Firenze. E-mail: lamberto.zollo@ unifi.it.

*** Università degli Studi di Milano. E-mail: alessandro.caliandro@unimi.it.

*** Università degli Studi di Firenze. E-mail: cristiano.ciappei@unifi.it. 


\section{Introduction}

Over recent decades, academic literature has started to explore the bidirectional relationship between brand and corporate reputation (Abratt and Kleyn, 2012). Corporate brand, defined as the combination of name, promises and symbols that identify a company (Argenti and Druckenmiller, 2004), is one of the fundamental elements influencing corporate reputation. Corporate reputation, which is identified as the aggregation of stakeholders' and consumers' perceptions about the company (Gray and Balmer, 1998), is related to sentiments that consumers hold about a brand. In particular, a sharp decrease in consumers' perceived corporate reputation may cause a decrease in consumers' level of trust towards the company (Rhee and Valdez, 2009). In the Web 2.0 era, characterized by an increase in the number of touch points between company and consumers (Yadav and Pavlou, 2014), monitoring corporate reputation and brand perceptions online may represent a way to avoid stakeholders' boycott (Edelman, 2010). Hence, strategies that enable companies to preserve corporate reputation are fundamental for preserving brand and survival of the company. Building on traditional literature about brand, corporate reputation and online response strategies, the aim of this paper is to explore through the analysis of a case how constant monitoring and digital counterattack strategies are an effective countermeasure to reputation attacks. Therefore, we investigate social media managers' ability to reduce the short-term negative brand perception during a reputation damaging event. Specifically, we analyse how such events affect customer-based reputation (CBR) (Walsh and Beatty, 2007).

This paper is structured as follows. First, literature about new branding strategies in the digital era will be illustrated. Second, the role of corporate reputation in influencing consumers' opinions about a brand will be analysed. Third, the principal strategies to preserve reputation in the digital era will be investigated. Finally, a digital investigation of 8,624 tweets on the Eni vs. Report case will be used in order to understand how digital counterattack strategies are able to influence CBR in the short term.

\section{Branding in the Digital Era}

Marketing researchers have pointed out the recent evolution of consumer-brand relationships due to digital platforms such as social networking sites (Edelman, 2010). Kaplan and Haenlein (2010) defined social media as «a group of internet based applications that builds on the ideological and technological foundations of Web 2.0, and it allows the creation and exchange of user-generated content»(p.61). Hence, the 
Social media strategies to protect brand image and corporate reputation in the digital era

diffusion of these new channels is deeply affecting the design of modern brand marketing strategies (Leeflang et al., 2014).

Since brand community has traditionally been defined as a «nongeographically bound community, based on a structured set of social relations among admirers of a brand» (Muniz and O'Guinn, 2001, p.412), it emerges that these social ties and touch points with consumers recently become digital relationships in online environments (Yadav and Pavlou, 2014). Online environments are composed of brand, consumers, products, and social networking sites, which are characterized by interactivity and bi-directionality. Virtual brand communities, defined as a «structured set of brand-consumer social relations articulated online»(Chi, 2011, p.47), hence become an innovative form of marketing communication prompting marketing strategists to enhance social connectivity and consumer monitoring. Thanks to new digital touch points with consumers, i.e., usergenerated brand related messages (Burmann, 2010), brand strategists need to dynamically adapt brand strategies in order to pay attention to consumers' feedbacks (Fournier and Avery, 2011). Consequently, recent researches have evidenced a progressive transformation in integrated marketing communication (Vernuccio and Ceccotti, 2015).

More recently, Edelman (2010) stressed a paradigmatic shift of modern consumer engagement. According to the author, while marketers traditionally used the "funnel" metaphor - consumers winnow their purchase choices starting from many brands to progressively fewer brands till a final choice - new marketers have to face the "consumer decision journey". This latter framework theorizes an iterative dynamic consumer decision based on three conventional stages: consider, evaluate, buy, and post-purchase stages, enjoy, advocate and bond. Specifically, the modern 'consumer journey' begins by considering a reduced set of product/services alternatives, often triggered by digital media stimuli. Then, this initial set is progressively modified by the consumer who evaluates other consumers' online feedbacks and experiences of those brands and alternative ones. The result is the product/service purchase, which highly affects the consumer-brand digital relationships and, subsequently, corporate reputation. In fact, consumers usually share their purchase experiences online and, in the case of positive experiences, «they'll advocate for it by word of mouth, creating fodder for the evaluations of others and invigorating a brand's potential» (Edelman, 2010, p. 3).

If the consumer enjoys his/her choice, a positive online advocacy will be triggered, strengthening online corporate reputation (Burman, 2010). In this case, one of the most significant consequences of modern brand management refers to the possible consumer "enjoy-advocate-buy loop", which allows a self-reinforcing direct link between positive online 
advocacy and the buy stage, thus skipping the consider and evaluate stages. This is why enhancing consumer advocacy represents a key driver for modern strategic marketers, who should exploit at best their "owned" and "earned" digital media channels in order to handle digital touch points during the consumer decision journey. Being present in the post-purchase stages, especially enjoy and advocate, allows brand managers to actively monitor the consumer decision journey through dynamic and live interaction with his/her comments, recommendations, and experiences.

One of the most significant consequences of social media marketing and the resulting virtual brand community is the role transformation of digitally involved actors. In fact, today consumers have become active marketers and professional consumers (Vescovi, 2008). Consequently, online environments and social networking sites allow a "two-way communication" between consumers and brand, providing an interactively and participatory bi-directional provision of information (Chi, 2011). Such an increased consumer engagement in digital environments gives rise to the concept of user-generated content (UGC) (Burmann, 2010); this refers to consumers' social expressions and communications through Web 2.0 digital platforms, such as brand reviews on social networking sites (Yadav and Pavlou, 2014). In this way, modern consumers may control marketing assets traditionally owned by companies (Vescovi, 2008).

In the digital era, brand strategists have to give online consumers' "voice" a pivotal active role (Gensler et al., 2013). It emerges that consumer-generated brand stories, both positive homages and negative complaints, are crucial in modern consumer-dominated digital environments, giving rise to what Fournier and Avery (2011) recently defined as "open source branding". According to them, this new paradigm implies "participatory, collaborative, and socially-linked behaviours whereby consumers serve as creators and disseminators of branded content» (p.194). In such a context, brand managers aim to protect brand reputation resulting from consumers' perceptions in virtual communities (Gensler et al., 2013). Building on this, Burmann (2010) validated the notion of usergenerated brand. Such a concept is coherent with modern, bi-directional communicative marketing, and is defined by Burman (2010) as the strategic management of brand-related UGC to achieve brand objectives. Hence, the paradigm shift in the integrated marketing communication poses new challenges for marketing strategists (Vernuccio and Ceccotti, 2015).

Finally, what still needs to receive attention in this nascent social media marketing paradigm refers to the way marketing managers monitor both pro- and anti-content, consumer-generated, brand stories, e.g. through a digital "alarm system" aimed at preserving brand image and corporate reputation. In this paper, we attempt to investigate such an important issue thanks to the analysis of how a micro-blogging site may be used for preserving corporate reputation and thus brand image (Vernuccio, 2010). 
Social media strategies to protect brand image and corporate reputation in the digital era

One of the most significant elements of our exploratory research refers to analysing how real-time digital response strategies may strengthen consumers' perceived image of the brand, avoiding also possible brand image damages.

\section{Brand image and corporate reputation}

Corporate reputation is defined by prevalent marketing literature as a result of the aggregation of stakeholders' personal perceptions on past actions, attributes, and outputs of the company (Gray and Balmer, 1998). In particular, corporate reputation has been deemed as dependent on company commitment towards corporate social responsibility (CSR) (Arru, 2015), managerial behaviour (Argenti and Druckenmiller, 2004) and products' quality (Podnar and Balmer, 2013). Corporate reputation, therefore, may be interpreted as the sum of overall evaluations that stakeholders make about company constituents. Anyway, since stakeholders may react to external stimuli (Rhee and Valdez, 2009), their opinions may switch from positive to negative and, as a consequence, corporate reputation may abruptly deteriorate. In such a context, marketing strategists' attention has progressively focused on customers' perceptions of companies (Fournier and Avery, 2011). As a result, the notion of CBR, defined as «the customer's overall evaluation of a company based on his or her reactions to the company goods, services, communication activities», recently received attention (Walsh and Beatty, 2007, p.129).

In order to analyse how digital counterattack strategies protect reputation and prevent 'anti-content' messages from damaging brand image, the next two sections are organized as follows. Firstly, in order to demonstrate why preserving reputation implies defending brand image, the bi-directional relationship between corporate identity, brand and corporate reputation will be explored. Then, the evolution of strategies to preserve corporate reputation will be traced.

\subsection{The bi-directional relationship between corporate identity, brand image, and corporate reputation}

Scholars from various disciplines have investigated the relationship between corporate identity, brand, and corporate reputation (Rhee and Valdez, 2009). The direct relationship between them will be analysed observing, firstly, the relationship between corporate identity and brand image (Argenti and Druckenmiller, 2004); then, the relationship between brand image and corporate reputation will be discussed (Abratt and Kleyn, 2012). 
Figure 1 - Corporate identity, brand and corporate reputation (adapted from: Abratt and Kleyn, 2012, p. 7)

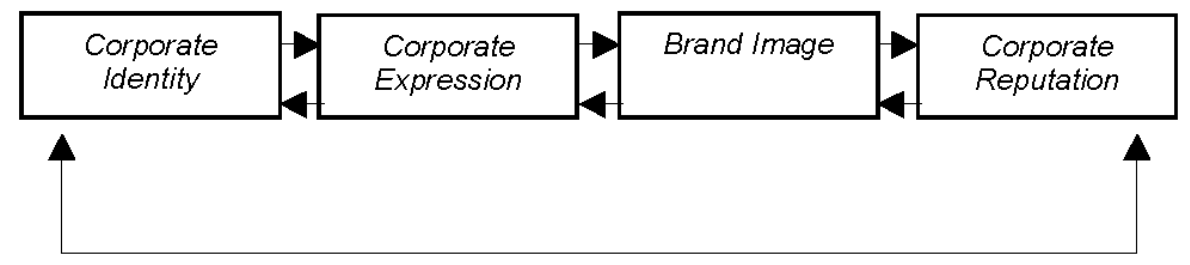

Gray and Balmer (1998) defined corporate identity as «the reality and uniqueness of the organization» (p. 695). The constituents of corporate identity are mission, vision, values and fundamental strategic choices (Podnar and Balmer, 2013). Corporate identity is a deeper concept in respect of both brand and corporate reputation. In fact, corporate identity is directly related to companies' inner core values. Instead, brand and corporate reputation are related to stakeholders' perceptions (Argenti and Druckenmiller, 2004). Despite such misalignments, corporate identity constituents concur directly with the formation of "corporate expression" and brand image (Abratt and Kleyn, 2012, p. 1049). More precisely, corporate identity influences corporate expression which itself influences brand image.

Hence, corporate expression and brand image compose the brand perceived by consumers and stakeholders. In particular, corporate expression is the component of brand directly descending from strategic choices of corporate identity (Podnar and Balmer, 2013). Brand image, instead, is the component of brand shaped by perceptions of brand communities and stakeholder experiences related to corporate brand (Argenti and Druckenmiller, 2004). As a result, since corporate identity and corporate brand are interrelated, changes in corporate identity will reflect on the image of brand, while changes in brand image may damage perceived corporate expression.

By virtue of the relationship between corporate identity and brand, the bi-directional relationship between brand and corporate reputation can be identified. In fact, since reputation is the aggregation of all stakeholder perceptions about a company, brand perceptions represent a significant part of the constituents of corporate reputation (Podnar and Balmer, 2013). Events harming reputation, hence, may end up damaging brand and causing brand equity dilution. Such events, eventually, may undermine stakeholder perceptions on how company products and services may be able to meet their expectations (Coombs, 1998). Moreover, in the worst case, brand capability of retaining consumers may be reduced (Pace et al., 2015). In the light of this bi-directional relationship, companies should adopt specific strategies in order to preserve brand image and corporate reputation, thus, as shown in Figure 2, avoiding damages to corporate identity and dissociation between corporate values and brand. 
Figure 2 - The impact of reputation damaging events on brand and corporate identity

\begin{tabular}{|c|c|c|c|c|}
\hline $\begin{array}{l}\text { Corporate } \\
\text { reputation } \\
\text { damaging } \\
\text { event } \\
\text { (affects } \\
\text { stakeholder } \\
\text { perceptions of } \\
\text { the company) }\end{array}$ & $\longrightarrow$ & $\begin{array}{l}\text { Brand } \\
\text { image } \\
\text { (reputation } \\
\text { damaging } \\
\text { event affects } \\
\text { perceived } \\
\text { capability of } \\
\text { brand to meet } \\
\text { consumer's } \\
\text { expectation) }\end{array}$ & Long-term & $\begin{array}{l}\text { Corporate } \\
\text { expression } \\
\text { and } \\
\text { perceived } \\
\text { values of the } \\
\text { company }\end{array}$ \\
\hline
\end{tabular}

\subsection{Strategies to preserve corporate reputation in the digital era}

Before the worldwide diffusion of the Internet, researches on responses to reputation damaging events focused on typologies of crises and the kinds of managerial responses (Rhee and Valdez, 2009). With regard to the kinds of crises, two main categories were identified by scholars. To the first category belong scandals involving the company or its management, e.g. scandals regarding CSR or bribery (Arru, 2015). To the second category belong accidents caused by the company. Instead, with regard to the managerial response strategies, three main strategies were prevalently used: (a) denying scandals to avoid further reputational damage; (b) reducing the magnitude of scandals or accidents; (c) rebuilding the damaged reputation (Coombs, 1998). In the absence of the Internet, managers in the past benefitted from more time to develop their responses. At that time the process was composed, first, by a fast fact checking, second by a phase of strategy planning, and third by effective actions. Also, the communication with stakeholders was usually constituted by monothematic defensive statements. Principal contents of such statements were formal attacks towards accusers, official denial, and excuses given to the alleged damaged party. Privileged channels selected for communication were traditional media, e.g. television or newspapers. One-way communicative strategies centred on formal general statements were the managerial praxis used to respond to reputation damaging events before the diffusion of the Internet (Rhee and Valdez, 2009).

In the Web 2.0 era, traditional strategies rapidly became unsufficient to cope with the new threats to corporate reputation and brand image (Aula, 2010). In fact, social networking sites have actually transformed communications with stakeholders from mono-directional to interactive. Consumers and stakeholders today have become "empowered" due to their 


\section{R. Rialti, L. Zollo, A. Caliandro, C. Ciappei}

participation in social networking sites' activities. The monitoring of their activities is becoming a priority for marketers (Muniz and O'Guinn, 2001). Wrongdoings and bad news digitally travel faster and diffuse worldwide (Champoux et al., 2012). Consequently, for companies it is becoming increasingly difficult to make their voice heard (Rhee and Valdez, 2009). The new threats deriving from social networking sites, thus, have significantly affected strategies to preserve corporate reputation. Today, such strategies are perpetually running processes composed of monitoring social networking sites, measuring reputation levels and participating in online discussions. Therefore, companies today should have a reputation manager capable of monitoring online corporate reputation and brand image, acting promptly, and managing an online dialogue. It has emerged how new managerial skills - such as digital, technical, social, and networking skills - become crucial for managing online communication (Vernuccio and Ceccotti, 2015, p.442).

According to the level of participation that the company wants to keep on social networking sites, reputation managers may choose to implement one of Aula's four strategies (2010, p.48) for preserving reputation on social networking sites: (a) strategy of absence, which means that companies simply monitor online corporate reputation and act only when necessary; (b) strategy of presence, which involves a slightly more major level of participation; (c) strategy of attendance, which involves effective dialogue but not necessarily real-time; (d) strategy of omnipresence, which contemplates constant monitoring by the company and constant dialogue with stakeholders. Companies following these new kinds of strategy, therefore, may be able to protect reputation and brand image in the digital era.

To our knowledge, apart from the many studies analysing the importance of corporate reputation and the related strategies (Coombs, 1998), scant attention has been dedicated to investigating the effectiveness of digital response strategies by observing consumers' and stakeholders' reactions - in particular, how those kinds of strategies are capable of reducing the short-term magnitude of reputational crisis. Moreover, scant attention has been dedicated by the literature to the importance of the reaction of social media managers.

Hence, our research question is:

$\mathrm{RQ}$ - Are constant monitoring and digital counterattack strategies able to preserve $C B R$ and reduce the short-term negative brand perception during a reputation damaging event?

Since studies on corporate reputation need to be evidence-based in order to allow scholars to extract managerial implications, we have developed a digital investigation of the Eni vs. Report case. 
Social media strategies to protect brand image and corporate reputation in the digital era

\section{A digital investigation of Eni vs. Report case}

In order to answer our research question, a qualitative analysis has been conducted on 8,624 tweets and the main Italian newspaper articles and blog sites concerning the Eni vs. Report case. Specifically, in order to understand how stakeholders have been influenced by real-time corporate communication, a digital investigation consisting of an automated analysis and a network analysis of users' interactions, considering the whole dataset, have been conducted; content analyses on 464 retweeted and the most relevant tweets have also been conducted.

\subsection{The Eni case ${ }^{1}$}

Eni is an Italian oil and gas company. It has control of the Italian distribution network of gas and it controls more than $20 \%$ of Italian petrol stations. Despite operating in the oil and gas sector, Eni has always tried to be a benchmark in its sector for commitment to CSR and transparency. As proof, Eni has been included in both the Dow Jones Sustainability World Index and the FTSE4Good Index. Despite the attention of Eni management towards CSR and transparency, on the night of $13^{\text {th }}$ December 2015, Eni found itself involved in a potential reputation damaging crisis when Report, a popular Italian investigative TV programme, attacked the company. Report journalists accused Eni of being involved in the payment of what has been considered the world's biggest bribe in Nigeria. Specifically, according to Report, Eni corrupted Nigerian governmental representatives for about $\$ 1.92 \mathrm{bn}$ in order to acquire concession no. OPL245 to extract around 9bn barrels of oil in Nigerian waters. Second, Eni was accused of having sold at a bargain price some of its less profitable subsidiaries. Finally, Report accused Eni of having polluted the waters of Gela, a Sicilian city. The same night, when the TV programme was still on air, Eni via its official Twitter account and its executive vice-president Marco Bardazzi's Twitter account, started a unique second-screen counterattack against Report. The Eni vs. Report case may be considered emblematic in the Italian panorama. In fact, this conflict represents one of the first cases in which a company and its reputation manager counterattack the criticisms in real-time using a social networking site.

\subsection{Methodology}

In order to answer our proposed research question, we conducted a digital investigation of 8,624 tweets concerning the Eni vs. Report case.

1. The authors of this article do not intend to go into the nature of the claims of the investigation into Eni vs. Report. 


\section{R. Rialti, L. Zollo, A. Caliandro, C. Ciappei}

Due to its relevance in the Italian context, a single case has been studied (Eisenhardt, 1989). We used only one social networking site, namely Twitter, because most of the attacks and counterattacks have been posted in such a social networking site $^{2}$. Moreover, some additional information concerning the selected case has been extracted from Italian newspapers and blog websites ${ }^{3}$. Our digital investigation consisted of mapping the activities and discourses articulated by Twitter users around the hashtags \#eni and \#report. Methodologically, this investigation was grounded in a combination of Digital Methods and Netnography (Arvidsson and Caliandro, 2015). We used a digital investigation because this methodology allows the extraction of detailed insights concerning the spreading of digital phenomena. Specifically, the combined assessment of conceptual maps and hashtags permits inferring consumers' perceptions about brand image and corporate reputation (Caliandro, 2014).

Digital Methods consist of a set of techniques «for the study of societal change and cultural condition with online data» (Rogers, 2015, p. 1). The Digital Methods paradigm invites the researcher to follow the medium, i.e., to consider the Internet as a source of methods rather than an object of study per se. Empirically, this epistemological exhortation translates into the systematic study of how «digital devices like search engines and social media platforms, and functions like Instagram's tags or Twitter's retweets, structure flows of information and communication» (Caliandro, 2014, p. 748) as well as users' interactions on the Internet. Instead, Netnography takes advantage of interpretative text analysis and participant observation for reconstructing online forms of sociality and webs of significance (Geertz, 1973).

On the one hand, we draw on the Digital Methods approach for detecting, circumscribing and studying the field of interaction in which Twitter's users deployed their activities and discourses about \#eni and \#report ${ }^{4}$, and on the other hand, we draw on the Netnographic approach for understanding thoroughly such activities and discourses.

\subsection{Datasets and analysis}

Our digital investigation is based on two datasets. The first consists of 6,602 tweets containing the hashtag \#report and the second of 2,022 tweets

2. According to Corriere della Sera, only a limited number of users have posted related content on other social networking sites: http://goo.gl/N07wp0.

3. We analysed relevant Italian newspapers, such as Corriere della Sera, La Repubblica, The Huffington Post Italia, Il Fatto Quotidiano; and important blog websites such as Wired Italia, Il Post, Webnews.it.

4. Those two hashtags were selected for our digital investigation because they were the main trending hashtags related to the case, as stressed by Wired.it: http://www.wired.it/play/televisione/2015/12/14/eni-report-social-tv/. 
Social media strategies to protect brand image and corporate reputation in the digital era

containing the hashtag \#eni (with an overlap of 390 tweets between the two datasets). We collected these tweets by using custom-built software, i.e., a Python script programmed for interrogating the Search $\mathrm{API}^{5}$ of Twitter (Russell, 2013). Since we were interested in a very specific time frame, we launched the script on the $15^{\text {th }}$ December, in order to be sure of gathering all the tweets we needed. We set the script for searching the following keywords: '\#report' and '\#eni' ${ }^{\text {. The }}$ 8,624 tweets were collected from $12^{\text {th }}$ to $15^{\text {th }}$ December 2015. Those tweets also include the two main streams of Eni's tweets and related accounts - i.e., Eni's vice president Marco Bardazzi and Eni's social media manager Daniele Chieffi - which mainly happened during the night of $13^{\text {th }}$ December ${ }^{7}$. Interestingly, in the days after $14^{\text {th }}$ December the tweeters' attention towards the case softened ${ }^{8}$.

Once all tweets had been collected, we submitted the two datasets to two different kinds of analysis: (a) network analysis; (b) qualitative content analysis.

(a) Network analysis. As far as the \#report dataset is concerned, we developed a network analysis aimed at mapping the structure of interaction among users tweeting with the hashtag \#report (Larsson and Moe, 2011). We focused on this dataset for the network analysis since we deemed it the most relevant, being the one with the highest amount of data. The network analysis focused on two specific metadata, i.e., @s plus RTs and \#s. As far as the network analysis of @ $\mathrm{s}$ and RTs is concerned, it was based on the in-link technique, which means that we focused on the @s and/or RTs received by each user. We considered users with a higher level of in-link, or in-degree, as more popular, as they were mentioned and/or retweeted more frequently than other users (Arvidsson et al., 2015). As far as the network analysis of \#s is concerned, it consisted of a co-hashtag analysis (Marres and Gerlitz, 2016), which, in turn, consists of the counting and analysis of the co-occurrence of hashtags within single tweets. Finally, the networks were visualised through Gephi, an open-source software for visualising and exploring graphs.

5. API is the acronym of Application Programming Interface. API is a set of procedures that software developers can use for accessing a set of data of a specific online platform (such as Twitter).

6. When searching for single keywords within a limited period of time (as in our case), there are no substantial limitations in terms of number of tweets that a user can obtain by interrogating the Twitter Search API. Thus, we are confident to have gathered all the available tweets.

7. According to Webnews.it, Eni's first main stream of tweets happened between 21:58 PM and 22:06 PM on 13th December, while the second stream happened during 22:37 PM and 22:56 PM: http://www.webnews.it/2015/12/14/report-eni/.

8. According to Corriere della Sera, the peak of tweets traffic related to the event was around $22 \mathrm{PM}$ on 13th December: http://goo.gl/N07wp0. 


\section{R. Rialti, L. Zollo, A. Caliandro, C. Ciappei}

(b) Qualitative content analysis. Qualitative content analysis consisted of the systematic reading and manual coding of the text of the tweets in order to identify their main topics of discussion (Poell and Borra, 2011). Specifically, we coded the tweets according to three categories: Pro Eni, Neutral, Against Eni (see Table 1). In order to categorize the 8,624 tweets, we used validated parameters to measure customers' perceptions towards corporate reputation following pertinent literature (Walsh and Beatty, 2007). In particular, we classified as Pro Eni those tweets expressing sympathy and appreciating fairness and social responsibility and transparency. Among these, tweeters showing appraisal at Eni's transparency were the most significant for our classification. Second, we considered as Neutral the tweets sharing the related content without expressing judgments on the company's counterattack. Finally, we identified as Against Eni the tweets characterized by negative attitudes criticizing Eni's transparency, fairness and social responsibility, thus showing a low level of sympathy and emotional affinity with the company. By counting the Pro Eni, Neutral, and Against Eni tweets we observed how Eni has been able to preserve CBR, minimizing the magnitude of the reputation attacks. In fact, by counting particularly the Pro Eni and the Against Eni tweets it's possible to observe the magnitude of a reputation damaging event by observing the predominance of anti-content or positive content messages (Burmann, 2010). For this reason we have considered only three categories.

Tweets that belong to one of these categories have been considered "on topic". In addition, we set a residual category "off topic", comprising all the tweets not falling into any of the aforementioned categories. The establishment of the categories of analysis followed a grounded and iterative process (Glaser and Strauss, 1967), insofar as the categories were not defined a priori, but gradually emerged during the reading of the digital texts, through a constant and collaborative examination by the four authors.

The sample for the qualitative analysis is composed of 464 tweets. These tweets have been selected according to two parameters; in particular, exclusively "on topic" tweets retweeted at least once have been sampled. Fundamentally, we used the RT function as a natively digital tool for sampling the stream of tweets, since it retrieved for us the messages that Twitter users themselves considered the most relevant (Arvidsson et al., 2015). As proof of that, the selected 464 tweets have been retweeted totally 6,111 times, hence representing $79.51 \%$ of the total volume of tweets concerning the case.

The sampling process is structured as follows. Firstly, retweets were excluded from the initial dataset. Hence, the number of tweets reduced from 8,264 to 1,797 . Second, the 552 tweets retweeted at least once of the 
Social media strategies to protect brand image and corporate reputation in the digital era

Table 1 - Illustration of coding criteria

$\begin{array}{ll}\begin{array}{l}\text { a) pro Eni tweets } \\ \text { Definition }\end{array} & \begin{array}{l}\text { Tweets that support Eni responses and practices } \\ \text { Example }\end{array} \\ \begin{array}{l}\text { - \#Eni has been the first company to attack while the } \\ \text { programme still airing \#Report social media manager and its } \\ \text { team deserve an Oscar. \#verygood https://twitter.com/ } \\ \text { francescachaouq/status/676269449553567744 }\end{array} \\ \begin{array}{ll}\text { b) neutral tweets } \\ \text { Definition }\end{array} \\ \begin{array}{l}\text { Tweets from users that simply want to share something about } \\ \text { the fact without taking part }\end{array} \\ \begin{array}{l}\text { - Everyone can have its own opinion, but please, follow the } \\ \text { event, it surely will become a case history in Italy \#Report. } \\ \text { https://twitter.com/pedroelrey/status/676153238899580928 }\end{array}\end{array}$

c) against Eni tweets

Definition Tweets that support Report and that hypothesize that Eni

$\begin{array}{ll} & \text { responses are not true. } \\ \text { Example } & - \text { \#Eni is a dishonest company. They are polluters and }\end{array}$ capitalists. Their response is just a \#Fail \#Eni. From Today

\#BoycottEni \#Report \#ReportRai3 https://twitter.com/ Reset_Italia/status/676561284310155264?lang = it

d) off topic tweets

Definition

Tweets that are not related to Eni vs. Report case but contain at least one of the two selected hashtags

Example - From tomorrow more benefit for holders of \#Eni fidelity card \#Telepass

https://twitter.com/auto_app/status/676393357858484224?lang = it

remaining 1,797 direct tweets were selected. Then, in order to retain only one of each of the overlapping tweets, 45 of the 90 remaining overlapping tweets were excluded. Finally, 43 "off topic" tweets, specifically 21 containing the hashtag \#Report and 22 containing the hashtag \#Eni, were removed (see Figure 3).

Chronologically, these 464 tweets are divided as follows: 395 tweets from $13^{\text {th }}$ December, 69 tweets from $14^{\text {th }}$ December. It is interesting to observe a decreasing trend immediately after the counterattack implemented by Eni, thus stressing the importance for marketing strategists to act in a real-time fashion. Regarding the $12^{\text {th }}$ December, only 2 tweets were found, which were both neutral tweets. As for $15^{\text {th }}$ December, 4 related tweets were found but they were all neutral and not retweeted. All the considered tweets were in Italian. 
Figure 3 - The definition of the sample

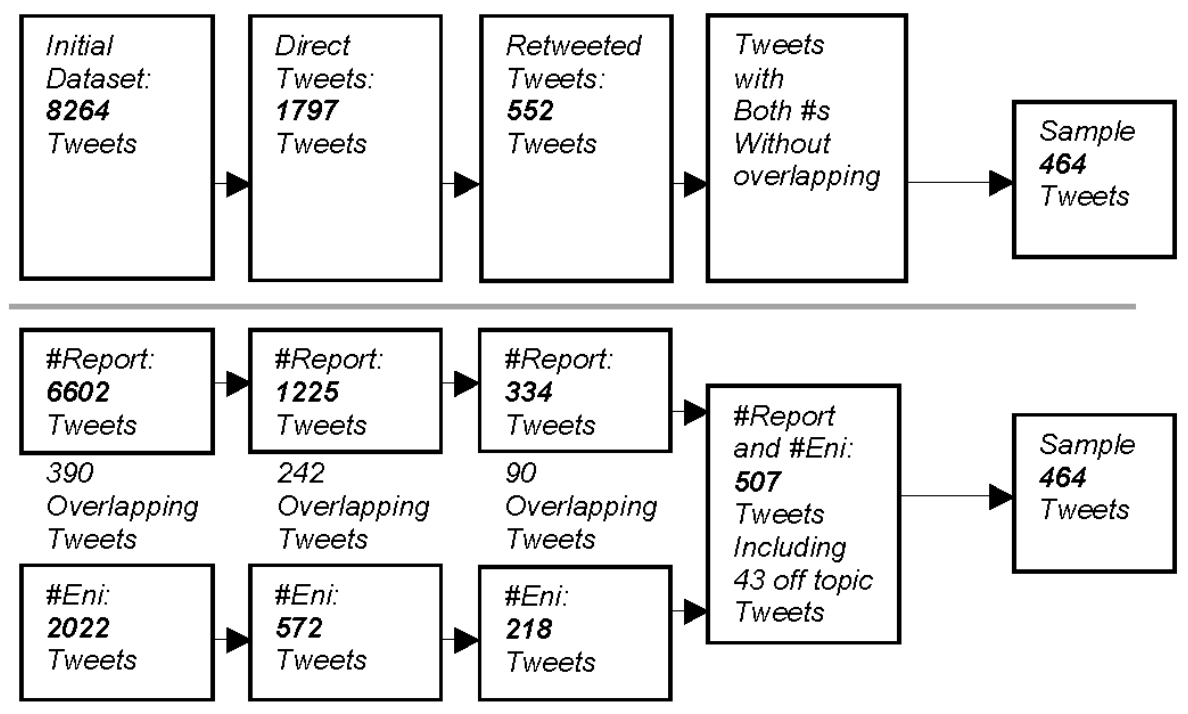

\section{Results}

From the digital investigation of Eni vs. Report case, two main results have been obtained. Firstly, from the network analysis emerged the diffusion of the tweets and the most popular hashtags connecting the hashtag \#report with the hashtag \#eni. Then, from the content analysis it was possible to understand how real-time digital response has been capable of affecting stakeholders' and customers' perception.

With regard to the results from the network analysis, the principal outcome is the graphical representation of the diffusion of hashtags around the \#report hashtag (see Figure 4a). In particular, by analysing the map it is possible to observe how the hashtag \#eni is the principal hashtag related to the hashtag \#report during the observed period. Moreover, it emerges that the hashtag \#eni is itself the only other aggregation point of tweets, apart from the hashtag \#report. Due to this result, it is possible to assess that Twitter users following Report were particularly interested in expressing their disappointment directly, using the hashtag \#eni. In the same way, Twitter users following \#eni were particularly interested in defending Eni attacking Report directly. The principal hashtags connecting the hashtag \#report to the hashtag \#eni were \#tangenti, \#inquinamento, \#gela, and \#Nigeria. Instead, the most frequent hashtags connecting the hashtag \#eni to the hashtag \#report were \#brandreputation, \#reputazione, \#realtime, \#secondscreen, \#crisismanagement and \#enivsreport. The main arguments moved against Eni by Report's supporters were requests for more information about the water pollution in Gela and alleged corruption of 
Social media strategies to protect brand image and corporate reputation in the digital era

Eni's managers. The main content of Eni's counterattacking replies concerned the sustainability standards of the company and documents proving transparency ${ }^{9}$. The most active Pro Eni accounts were Eni.com (29 tweets; 883 RTs), Marco Bardazzi (6 tweets; 417 RTs), jacopopaoletti (5 tweets; 39 RTs), and Gianni Riotta (2 tweets; 78 RTs); the most active Against Eni tweeters were reportrai3 (28 tweets; 1,601 RTs), ducana2 (12 tweets; 94 RTs), stuppi86 (18 tweets; 75 RTs), and ilfattoquotidiano (2 tweets; 76 RTs). Notwithstanding the large amount of reportrai3's retweets, the retweets supporting Eni have been greater in number.

A second interesting result from the network analysis refers to the graphical representation of the most influential users (see Figure $4 b$ ). Particularly, it emerges that the most active Twitter account was the Eni account.

Figure $4 \mathrm{a}$ - The cloud of hashtag 'orbiting' around the hashtag \#Report

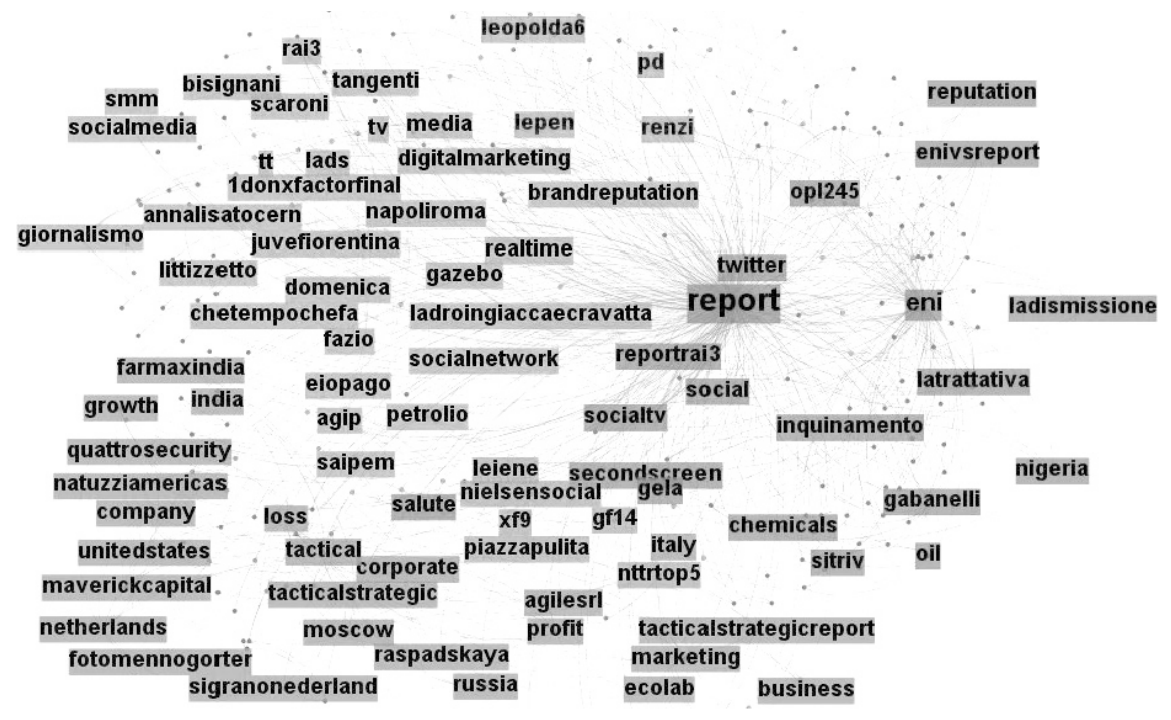

Figure $4 b-$ The network analysis of the most influential users

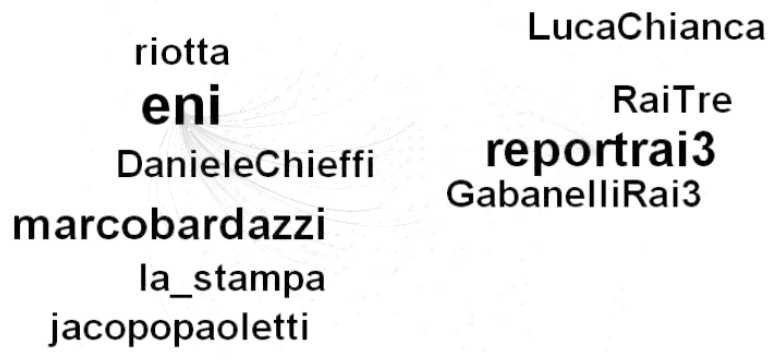

9. As an example: https://twitter.com/eni?ref_src=twsrc\%5Etfw. 
R. Rialti, L. Zollo, A. Caliandro, C. Ciappei

Table 2 - Temporal distribution of Pro Eni Tweets, Neutral and Against Eni Tweets

\begin{tabular}{llllll}
\hline $\begin{array}{l}\text { Day of } \\
\text { Observation }\end{array}$ & $\begin{array}{l}\text { Pro Eni } \\
\text { Tweets }\end{array}$ & $\begin{array}{l}\text { Neutral } \\
\text { Tweets }\end{array}$ & $\begin{array}{l}\text { Against } \\
\text { Eni } \\
\text { Tweets }\end{array}$ & $\begin{array}{l}\text { Total } \\
\text { Tweets } \\
\text { each day }\end{array}$ \\
\hline $13-12$ & $\begin{array}{l}\text { Number } \\
\text { of Tweets } \\
\% \text { of } 13-12\end{array}$ & 222 & 86 & 87 & 395 \\
$14-12$ & $\begin{array}{l}\text { Number } \\
\text { of Tweets }\end{array}$ & 35 & 18 & 16 & 69 \\
$\begin{array}{l}\text { \% of 14-12 } \\
\text { Total of }\end{array}$ & $\begin{array}{l}\text { Number } \\
\text { of Tweets } \\
\text { period }\end{array}$ & 257 & $\mathbf{2 1 . 7 7 \%}$ & $\mathbf{2 2 . 0 3 \%}$ & \\
\hline
\end{tabular}

With regard to the content analysis, two principal results emerged from the analysis of tweets (see Table 2). Firstly, regarding the temporal distribution, the $13^{\text {th }}$ December users posted 222 Pro Eni, 86 Neutral and 87 Against Eni tweets. The 222 were retweeted 2,639 times, the 861,587 times, and the 871,468 times. On the $14^{\text {th }}$ December, users posted 35 Pro Eni, 18 Neutral and 16 Against Eni tweets. The 35 were retweeted 142 times, the 1871 times, and the 16122 times.

With regard to the analysis of the most discussed topics, the results of the main observed keywords taken from the 464 tweets are the following: 22 tweets (retweeted 40 times) containing the hashtag \#brandreputation, which were all Pro Eni tweets; 6 tweets (retweeted 55 times) containing the hashtag \#reputationmanagement, which were all Pro Eni tweets; 2 tweets (retweeted twice containing the hashtag \#factchecking addressed to Report, which were all Pro Eni tweets; finally, 12 tweets (retweeted 50 times) containing the hashtag \#casehistory, which were 5 Pro Eni and 7 Neutral. Intriguingly, Eni has successfully given a live counterattack concerning the Report accusation of having polluted the waters of Gela. Such a reputation defence has been retweeted 165 times, which is the highest number in respect of the overall 158 tweets, retweets included, asking for more information about the possible Gela scandal.

\section{Managerial implications}

From the analysis of our explorative research, it is possible to affirm that a constant monitoring of social networking sites and digital counterattack strategies may be effective in preserving CBR by reducing 
Social media strategies to protect brand image and corporate reputation in the digital era

the magnitude of the reputation damaging event. Second, real-time digital response strategies based on transparency during an accusation of corruption are able to avoid perceived corporate identity damages. Hence, such responses succeed in highlighting the positive image and values of a company, thus avoiding a reputation damaging event impacting on stakeholders' and consumers' perceptions of a company.

One of the main findings of the research refers to the importance of well-planned digital counterattack responses. Particularly, it emerged how using interactive social networking sites - such as Twitter - for counterattacking a TV programme may result in gaining attention from opinion leaders and creating followership. Hence, it is possible to create a level battlefield through a strategic planned communication even when one of the actors is disadvantaged. Three empirical evidences emerged from the analysis to validate this assumption. First, the total of direct Pro Eni tweets (222 retweeted 2,639 times) greatly outnumber Against Eni tweets (87 retweeted 1,468 times) after the digital response. Second, it emerges that stakeholders and potential consumers themselves realized the effectiveness of Eni's response to the accusation by tagging their tweets with hashtags such as \#brandreputation, \#reputationmanagement, and \#casehistory. Finally, 27 tweets (retweeted 188 times) of the 464 analysed started by directly attacking Report's way of conducting journalism.

The main managerial implications refer to (1) the fact that having a social media communication team led by an expert may represent a competitive resource in the digital environment. (2) Disposing of an emergency digital counterattack strategy may strengthen a company's reactiveness; however, the counterattack should neither anticipate nor exceed the actual attack and its intensity. (3) Exploiting a social networking site populated by journalists and opinion leaders may increase followership and amplify the counterattack, thus enhancing its effectiveness. Consequently, well-planned digital counterattack strategies may be able to realize a 're-framing' of stakeholders' and consumers' perception, thus preserving CBR. Although these findings are not generalizable, as far as concerns our explorative research, constant monitoring and digital counterattack strategies emerged as important in preserving CBR and reducing the short-term negative brand perception during a reputation damaging event.

Finally, real-time digital responses avoid the multiplying effect of anticontent messages and their spreading across social networking sites. In fact, such responses may be able to avert the negative trend of messages, thus fostering the diffusion of pro-content messages. Further, the institutional response by the company represents an incentive for social networking sites' users to be motivated in expressing their opinions against the accuser. 


\section{Conclusions}

The present research builds on the recent literature on strategies to preserve corporate reputation in the digital era. The main contribution of the research refers to empirically analysing how digital counterattack strategies may avoid loss of reputation on social networking sites. Particularly, we analysed how a well-planned counterattack on social networking sites may be effective in preserving CBR and reducing the short-term negative brand perception during a reputation damaging event. Further, we also stress the importance of competent reputation managers able to actively counterattack. Actually, from the analysis it emerged that instant counterattacks imply a dilution of short-term negative critiques from both stakeholders and customers.

However, the study presents some limitations. First, the analysed time period is relatively short. Second, since the event is recent, it was not possible to implement a longitudinal analysis. Finally, since our research investigated a single case and only one social networking site, the results are not generalizable. Future researches may deepen the results by comparing a successful and an unsuccessful digital response via social networking studies. Particularly, it would be interesting to expand the present research to different contexts, such as fashion and the automotive industries, where more structured brand communities exist. Moreover, we suggest future researchers explore similar cases by using a sentiment analysis, since this would allow a better comprehension of stakeholders' and customers' feedback.

\section{References}

Abratt R. \& Kleyn N. (2012). Corporate identity, corporate branding and corporate reputations: Reconciliation and integration. European Journal of Marketing, 46(7/8): 1048-1063, doi: 10.1108/03090561211230197.

Argenti P.A. \& Druckenmiller B. (2004). Reputation and the corporate brand. Corporate Reputation Review, 6(4): 368-374, doi: 10.1057/palgrave.crr.1540005

Arru B. (2015). Indagine sulla comunicazione della responsabilità sociale delle società quotate italiane. Mercati e Competitività, 4: 15-46, doi: 10.3280/MC2015-004002.

Arvidsson A. \& Caliandro A. (2015). Brand public. Journal of Consumer Research, doi: 10.1093/jcr/ucv053. Available at: http://jcr.oxfordjournals.org/content/jcr/early/ 2015/11/10/jcr.ucv053.full.pdf?ijkey=OF0S6JvDZVVir4d\&keytype=ref, date accessed: 02 April 2016.

Arvidsson A., Caliandro A., Arioldi M. \& Barina S. (2015). Crowds and value. Italian Directioners on Twitter. Information, Communication \& Society, 19(7): 921-939, doi: 10.1080/1369118X.2015.1064462.

Aula P. (2010). Social media, reputation risk and ambient publicity management. Strategy \& Leadership, 38(6): 43-49, doi: 10.1108/10878571011088069. 
Burmann, C. (2010). A call for 'user-generated branding'. Journal of Brand Management, 18(1): 1-4, doi: 10.1057/bm.2010.30.

Caliandro A. (2014). Ethnography in Digital Spaces: Ethnography of Virtual Worlds, Netnography, and Digital Ethnography, In Sunderland, P. \& Denny, R. (eds.), Handbook of Anthropology in Business, Walnut Creek, CA: Left Coast Press. 738761.

Champou V., Durge J. \& McGlyn L., (2012). Corporate Facebook pages: when "fans" attack. Journal of Business Strategy, 33(2): 22-30, doi: 10.1108/02756661211206717.

Chi H.H. (2011). Interactive digital advertising vs. virtual brand community: Exploratory study of user motivation and social media marketing responses in Taiwan. Journal of Interactive Advertising, 12(1): 44-61, doi: 10.1080/15252019.2011.10722190.

Coombs W.T. (1998). An analytic framework for crisis situations: Better responses from a better understanding of the situation. Journal of Public Relations Research, 10(3): 177-191, doi: 10.1207/s1532754xjprr1003_02.

Edelman D.C. (2010). Branding in the digital age. Harvard Business Review, 88(12): 62-69.

Eisenhardt K.M. (1989). Building theories from case study research. Academy of Management Review, 14(4), 532-550, doi: 10.5465/AMR.1989.4308385.

Fournier S. \& Avery J. (2011). The uninvited brand. Business Horizons, 54(3), 193207, doi: 10.1016/j.bushor.2011.01.001

Geertz C. (1973). The Interpretation of Cultures. New York: Basic Books.

Gensler S., Völckner F., Liu-Thompkins Y. \& Wiertz C. (2013). Managing brands in the social media environment. Journal of Interactive Marketing, 27(4): 242-256, doi: 10.1016/j.intmar.2013.09.004.

Glaser BG. \& Strauss A.L. (1967). The Discovery of Grounded Theory: Strategies for Qualitative Research, Chicago: Aldine.

Gray E.R. \& Balmer J.M. (1998). Managing corporate image and corporate reputation. Long Range Planning, 31(5): 695-702, doi: 10.1016/S0024-6301(98)00074-0.

Kaplan A.M. \& Haenlein M. (2010). Users of the world, unite! The challenges and opportunities of Social Media. Business Horizons, 53(1), 59-68, doi: 10.1016/j.bushor.2009.09.003.

Larsson A.O. \& Moe H. (2011). Studying political microblogging in the 2010 Swedish election campaign. New Media \& Society, 14(5): 729-747, doi: $10.1177 / 1461444811422894$.

Leeflang P.S., Verhoef P.C., Dahlström P. \& Freundt T. (2014). Challenges and solutions for marketing in a digital era. European Management Journal, 32(1), 112, doi: 10.1016/j.emj.2013.12.001.

Marres N. \& Gerlitz C. (2016). Interface methods: renegotiating relations between digital social research, STS and sociology. The Sociological Review, 64(1), 21-46, doi: 10.1111/1467-954X.12314.

Muniz Jr A.M. \& O'Guinn T.C. (2001). Brand community. Journal of Consumer Research, 27(4): 412-432, doi: 10.1086/319618.

Pace S., Gistri G. \& Balboni B. (2015). L'impatto della brand crisis sulla clientela e l'effetto della fedeltà alla marca. Mercati e Competitività, 3: 103-121, doi: 10.3280/MC2015-003006.

Podnar K. \& Balmer J.M. (2013). Contemplating Corporate Marketing, Identity and Communication. London: Routledge.

Poell T. \& Borra E.K. (2011). Twitter, YouTube, and Flickr as platforms of alternative journalism: the social media account of the 2010 Toronto G20 protests. Journalism, 13(6): 695-713, doi: 10.1177/1464884911431533. 


\section{R. Rialti, L. Zollo, A. Caliandro, C. Ciappei}

Rhee M. \& Valdez M.E. (2009). Contextual factors surrounding reputation damage with potential implications for reputation repair. Academy of Management Review, 34(1): 146-168, doi: 10.5465/AMR.2009.35713324.

Rogers R. (2015). Digital Methods for Web Research. In Scott R. \& Kosslyn S. (eds.), Emerging Trends in the Behavioral and Social Sciences. Hoboken, NJ: Wiley.

Russell M.A. (2013). Mining the social Web: Data mining Facebook, Twitter, LinkedIn, Google+, GitHub, and more. Cambridge: O'Reilly Media.

Vernuccio M. (2010). I Social Media e il loro impiego nelle strategie di Corporate branding: un'indagine esplorativa. Micro \& Macro Marketing, 2: 189-214, doi: 10.1431/32512:y:2010:i:2:p:189-214.

Vernuccio M. \& Ceccotti F. (2015). Strategic and organisational challenges in the integrated marketing communication paradigm shift: A holistic vision. European Management Journal, 33(6), 438-449, doi: 10.1016/j.emj.2015.09.001.

Vescovi T. (2008). I clienti invadenti e il marketing non convenzionale. Micro \& Macro Marketing, 17(3): 449-454, doi: 10.1431/28479.

Walsh G. \& Beatty S.E. (2007). Customer-based corporate reputation of a service firm: scale development and validation. Journal of the Academy of Marketing Science, 35(1), 127-143, doi: 10.1007/s11747-007-0015-7.

Yadav M.S. \& Pavlou P.A. (2014). Marketing in computer-mediated environments: Research synthesis and new directions. Journal of Marketing, 78(1): 20-40, doi: 10.1509/jm.12.0020. 